Article

\title{
Fast Profiling of Natural Pigments in Different Spirulina (Arthrospira platensis) Dietary Supplements by DI-FT-ICR and Evaluation of their Antioxidant Potential by Pre-Column DPPH-UHPLC Assay
}

\author{
Eduardo Sommella ${ }^{1}$, Giulio Maria Conte ${ }^{1,2}$, Emanuela Salviati ${ }^{1,2}$, Giacomo Pepe ${ }^{1}$, \\ Alessia Bertamino ${ }^{1}$, Carmine Ostacolo ${ }^{3}$, Francesca Sansone ${ }^{1}$, Francesco Del Prete ${ }^{4}$, \\ Rita Patrizia Aquino ${ }^{1}$ and Pietro Campiglia ${ }^{1,5, *}$ (1)
}

1 Department of Pharmacy, University of Salerno, Via Giovanni Paolo II 132, I-84084 Fisciano, SA, Italy; esommella@unisa.it (E.So.); gconte@unisa.it (G.M.C.); esalviati@unisa.it (E.Sa.); gipepe@unisa.it (G.P.); abertamino@unisa.it (A.B.); fsansone@unisa.it (F.S.); aquinorp@unisa.it (R.P.A.)

2 PhD Program in Drug Discovery and Development, University of Salerno, Via Giovanni Paolo II 132, I-84084 Fisciano, SA, Italy

3 Department of Pharmacy, University of Naples Federico II, Via D. Montesano 49, I-80131 Napoli, Italy; ostacolo@unina.it

4 Department of Biology, University of Naples Federico II, Via Mezzocannone 16, I-80131 Napoli, Italy; francesco.delprete@unina.it

5 European Biomedical Research Institute of Salerno, Via De Renzi 50, I-84125 Salerno, Italy

* Correspondence: pcampiglia@unisa.it; Tel.: +39-089-969-250

Academic Editor: Nicola Marchetti

Received: 20 April 2018; Accepted: 10 May 2018; Published: 11 May 2018

\begin{abstract}
Arthrospira platensis, better known as Spirulina, is one of the most important microalgae species. This cyanobacterium possesses a rich metabolite pattern, including high amounts of natural pigments. In this study, we applied a combined strategy based on Fourier Transform Ion Cyclotron Resonance Mass Spectrometry (FT-ICR-MS) and Ultra High-Performance Liquid Chromatography (UHPLC) for the qualitative/quantitative characterization of Spirulina pigments in three different commercial dietary supplements. FT-ICR was employed to elucidate the qualitative profile of Spirulina pigments, in both direct infusion mode (DIMS) and coupled to UHPLC. DIMS showed to be a very fast $(4 \mathrm{~min})$ and accurate (mass accuracy $\leq 0.01 \mathrm{ppm})$ tool. 51 pigments were tentatively identified. The profile revealed different classes, such as carotenes, xanthophylls and chlorophylls. Moreover, the antioxidant evaluation of the major compounds was assessed by pre-column reaction with the DPPH radical followed by fast UHPLC-PDA separation, highlighting the contribution of single analytes to the antioxidant potential of the entire pigment fraction. $\beta$-carotene, diadinoxanthin and diatoxanthin showed the highest scavenging activity. The method took $40 \mathrm{~min}$ per sample, comprising reaction. This strategy could represent a valid tool for the fast and comprehensive characterization of Spirulina pigments in dietary supplements, as well as in other microalgae-based products.
\end{abstract}

Keywords: carotenoids; DIMS; DPPH; FT-ICR; Spirulina; UHPLC

\section{Introduction}

In the last decade, the food and pharmaceutical sector has been driven towards an interest in natural compounds that, if assumed on a daily basis, could bring benefits to human health, especially in the treatment of chronic diseases [1]. This led to the development of so-called nutraceuticals and 
functional foods, whose market is continually growing, helped by the interest of healthy conscious consumers. Among the natural matrices rich in bioactive compounds, microalgae represent one of the most promising [2]. These microorganisms are a source of various biologically active molecules, including aminoacids, polyunsaturated fatty acids, minerals, proteins and pigments [3]. Additionally, they are capable of growing in different aquatic environments, and can tolerate different temperatures, $\mathrm{pH}$ and salinities [4]. Arthrospira platensis, also known as Spirulina, is one of the most economically important species. This blue-green microalga has been widely commercialized and is sold in different forms, including as powder, tablets and creams. The high interest in Spirulina derives from numerous healthy properties attributed to the consumption of this microalga, which include antihypertensive, hypolipidemic, anticancer and antioxidant properties [5]. These properties are related to the outstanding content of biocompounds; in particular, Spirulina is characterized by a protein content that is roughly ten times higher than that of soybean [6]; moreover, it contains essential amino acids, polyunsaturated fatty acids, vitamins and pigments. Spirulina-based products are employed by athletes as anti-fatigue and amino acid supply, and for their anti-aging detoxifying and antioxidant properties in cosmetics. The antioxidant potential of Spirulina is partially attributed to the high content of natural pigments, especially carotenoids, which are also recognized as having numerous healthy benefits [7]. Carotenoids are a group of molecules characterized by a C40 chain of isoprene units synthetized by plants and microorganisms, and are usually colored [8]. They are distinct in primary, which are involved in the photosynthetic apparatus, and in secondary, that are produced by microalgae following a particular situation of stress [9]. Despite the success of Spirulina in the market, the profiling of pigment in this species has been only partially described. The determination of carotenoids in Spirulina has been carried out mainly by liquid chromatography (LC) coupled with diode array (DAD) and mass spectrometry (MS) detection by employing low-resolution mass analyzers [10], and recently also by high-performance thin layer chromatography (HPTLC) [11]. Given that the Spirulina pigment fraction is highly complex, conventional LC-MS-based methods suffer from a low separation efficiency, long analysis time, and low mass accuracy, which can result in inaccurate identification. Furthermore, the antioxidant activity of carotenoid extracts has been evaluated by spectrophotometric or enzymatic assays [12,13], which reflect only the total activity of the extract, without adequate measure of the antioxidant potential of individual molecules. Due to the increasing commercial interest in Spirulina, faster and more highly efficient analytical tools are required to characterize the final products and raw materials. In this regard, the objective of this study was to develop a combined platform for the qualitative and quantitative characterization of Spirulina pigments in different dietary supplements. To tackle such a task, we exploited the accurate mass measurement and resolution of Fourier Transform Ion Cyclotron (FT-ICR) for the qualitative profiling of the extract in both direct infusion (DIMS) mode or coupled with Ultra High-Performance Liquid Chromatography (UHPLC). Moreover, the antioxidant potential of major carotenoids was evaluated by the combination of pre-column reaction with 2,2-diphenyl-1-picrylhydrazyl radical (DPPH) followed by UHPLC separation, in order to obtain information regarding the contribution of individual pigments to the global antioxidant activity.

\section{Results and Discussion}

\subsection{High-Resolution Mass Spectrometry Profiling of Spirulina Pigments}

FT-ICR-MS is characterized by unmatched ultra-high mass accuracy and resolution, which are ideal for the analysis of complex phytochemical samples [14]. In this approach, we employed APCI ionization, which outperformed electrospray for almost all analytes in both DIMS and LC-MS modes (data not shown). Table 1 shows the tentative identification relative to both approaches. As can be observed, a higher number of tentatively identified compounds (51) was obtained by both DIMS and LCMS with respect to previous investigations on Spirulina [10]. Ultra-high mass accuracy was obtained for DIMS ( $\leq 0.01 \mathrm{ppm})$, while slightly higher values were obtained for LC-MS. This is relative to the intrinsic nature of FT-ICR, since the long scanning time required for ultra-high resolution is not 
very compatible with fast UHPLC timescales [15]. Contrariwise, direct infusion, which introduces constant ion flow, makes it possible to obtain the highest sensitivity, as well as accuracy and resolution. Ultra-high mass accuracy is highly beneficial to unambiguous formula assignment, and compounds can be identified often only by accurate mass [16]. Different carotenoid classes were present: hydroxyl, epoxy and ketocarotenoids, as well as carotenes; several compounds are reported for the first time in Spirulina (Table 1). Among hydroxycarotenoids, the peak at rt: 3.69 possessing strong absorbance at $450 \mathrm{~nm}$, showed the typical loss of water $[\mathrm{M}+\mathrm{H}-18]^{+}$, with a molecular formula of $\mathrm{C}_{40} \mathrm{H}_{54} \mathrm{O}_{2}$, and thus it was tentatively proposed to be diatoxanthin. Regarding epoxy derivatives, the peak at rt: 3.29 was characterized by the diagnostic fragment ion at $m / z 221\left(\mathrm{C}_{14} \mathrm{H}_{21} \mathrm{O}_{2}\right)$, which is derived from the cleavage between the $\mathrm{C} 10$ and $\mathrm{C} 11$ bond (Figure 1A) and was tentatively identified as diadinoxanthin. Similarly, other compounds of this class showed an analogous fragmentation pattern [17]. Compound 18 exhibited a diagnostic fragment ion at $203 \mathrm{~m} / z\left(\mathrm{C}_{14} \mathrm{H}_{18} \mathrm{O}\right)$, which points out a keto group on the $\mathrm{B}$-ring. This fragment is observed in keto derivatives [18] deriving from the fragmentation at $\mathrm{C} 10-\mathrm{C} 11$, in which the positive charge is retained on the ketone moiety. Thus, this information and the molecular formula $\mathrm{C}_{40} \mathrm{H}_{54} \mathrm{O}$, leads to possible identification as echinenone (Figure 1B). A large number of chlorophyll derivatives were detected, and some of them, such as divinyl chlorophyll a, presented the fragment at $m / z 614\left(\mathrm{C}_{35} \mathrm{H}_{34} \mathrm{MgN}_{4} \mathrm{O}_{5}\right)$, which indicates a phytyl chain loss. Hydroxylated derivatives of pheophytin and chlorophyll a showed a mass difference of 16 Da with respect to accurate mass, and their fragmentation patterns showed a loss of water [-18 Da]. Hydroxylated compounds could derive from transformations that occur during the extraction process [19]. A further benefit of DIMS is the analysis time, which was half of the LCMS method: 4 min vs. 16 min (Figure 2). Clearly, one of the drawbacks of DIMS is the inability to separate isomers, which, on the other hand, is possible using chromatography. The DIMS approach is highly useful when combined with other complementary techniques, as showed recently by several authors [20]. 
Table 1. DIMS-APCI and LC-APCI-FT-ICR MS identification of Spirulina pigments.

\begin{tabular}{|c|c|c|c|c|c|c|c|c|}
\hline Peak & rt & Compound & $\begin{array}{l}\text { Molecular } \\
\text { Formula }\end{array}$ & $\begin{array}{c}{[\mathrm{M}+\mathrm{H}]^{+}} \\
\text {DIMS-APCI }\end{array}$ & $\begin{array}{l}\text { Error ppm } \\
\text { DIMS-APCI }\end{array}$ & $\begin{array}{c}{[\mathrm{M}+\mathrm{H}]^{+}} \\
\text {LC-APCI-FT-ICR } \\
\text { MS }\end{array}$ & MS/MS & $\begin{array}{c}\text { Error ppm } \\
\text { LC-APCI-FT-ICR } \\
\text { MS }\end{array}$ \\
\hline 1 & 1.87 & Apo-12-Violaxanthal ${ }^{1}$ & $\mathrm{C}_{25} \mathrm{H}_{34} \mathrm{O}_{3}$ & 383.25809 & -0.05 & 383.25815 & $365.24754^{2}, 347.23705^{3}$ & -0.21 \\
\hline 2 & 2.76 & Vaucheriaxanthin ${ }^{1}$ & $\mathrm{C}_{40} \mathrm{H}_{56} \mathrm{O}_{5}$ & 617.42010 & -0.08 & 617.41998 & $599.40933^{2}, 581.39890^{3}$ & 0.12 \\
\hline 3 & 3.29 & Diadinoxanthin ${ }^{1}$ & $\mathrm{C}_{40} \mathrm{H}_{54} \mathrm{O}_{3}$ & 583.41458 & -0.02 & 583.41456 & $565.40420^{2}, 221.15364$ & 0.01 \\
\hline 4 & 3.33 & Canthaxanthin & $\mathrm{C}_{40} \mathrm{H}_{52} \mathrm{O}_{2}$ & 565.40402 & -0.01 & 565.40404 & $547.39350^{2}$ & -0.06 \\
\hline 5 & 3.45 & Ethyl $\beta$-apo- $8^{\prime}$-carotenoate ${ }^{1}$ & $\mathrm{C}_{32} \mathrm{H}_{44} \mathrm{O}_{2}$ & 461.34143 & -0.04 & 461.34155 & & -0.32 \\
\hline 6 & 3.67 & Adonirubin ${ }^{1}$ & $\mathrm{C}_{40} \mathrm{H}_{52} \mathrm{O}_{3}$ & 581.39892 & 0.01 & 581.39891 & & 0.02 \\
\hline 7 & 3.69 & Diatoxanthin ${ }^{1}$ & $\mathrm{C}_{40} \mathrm{H}_{54} \mathrm{O}_{2}$ & 567.41967 & -0.02 & 567.41971 & $221.13248,549.40979^{2}$ & -0.09 \\
\hline 8 & 3.78 & $\beta$-Apo- $8^{\prime}$-carotenal ${ }^{1}$ & $\mathrm{C}_{30} \mathrm{H}_{40} \mathrm{O}$ & 417.3152 & -0.01 & 417.31542 & $399.30463^{2}, 293.22642$ & -0.34 \\
\hline 9 & 3.85 & Hexadehydro- $\beta, \beta$-caroten-3-ol ${ }^{1}$ & $\mathrm{C}_{40} \mathrm{H}_{50} \mathrm{O}$ & 547.39347 & -0.06 & 547.39344 & & -0.36 \\
\hline 10 & 3.88 & Rhodoxanthin ${ }^{1}$ & $\mathrm{C}_{40} \mathrm{H}_{50} \mathrm{O}_{2}$ & 563.38838 & -0.04 & 563.38856 & $545.37778^{2}$ & -0.36 \\
\hline 11 & 3.90 & Astaxanthin & $\mathrm{C}_{40} \mathrm{H}_{52} \mathrm{O}_{4}$ & 597.39382 & 0.02 & 597.39384 & & 0.01 \\
\hline 12 & 4.04 & Antheraxanthin ${ }^{1}$ & $\mathrm{C}_{40} \mathrm{H}_{56} \mathrm{O}_{3}$ & 585.43023 & -0.02 & 585.43029 & $\begin{array}{c}567.41961^{2}, 549.40920^{3} \\
493.40407\end{array}$ & -0.12 \\
\hline 13 & 4.20 & Myxoxanthophyll & $\mathrm{C}_{46} \mathrm{H}_{66} \mathrm{O}_{7}$ & 731.48807 & 0.08 & 731.48917 & & -1.42 \\
\hline 14 & 4.38 & Zeaxanthin & $\mathrm{C}_{40} \mathrm{H}_{56} \mathrm{O}_{2}$ & 569.43529 & 0.02 & 569.43552 & $551.42497^{2}, 459.36256$ & -0.37 \\
\hline 15 & 5.06 & 10 -Apo- $\beta$-carotenal ${ }^{1}$ & $\mathrm{C}_{27} \mathrm{H}_{36} \mathrm{O}$ & 377.28389 & -0.06 & 377.28403 & & -0.37 \\
\hline 16 & 6.10 & $\alpha$-tocopherol ${ }^{1}$ & $\mathrm{C}_{29} \mathrm{H}_{50} \mathrm{O}_{2}$ & 431.38835 & 0.01 & 431.37971 & & -0.91 \\
\hline 17 & 8.73 & Chlorophyll $a$ isomer & $\mathrm{C}_{55} \mathrm{H}_{72} \mathrm{MgN}_{4} \mathrm{O}_{5}$ & 893.54226 & -0.03 & 893.54274 & $\begin{array}{c}555.22547,481.18779 \\
614.23848\end{array}$ & -0.17 \\
\hline 18 & 8.74 & Echinenone $^{1}$ & $\mathrm{C}_{40} \mathrm{H}_{54} \mathrm{O}$ & 551.42473 & 0.02 & 551.42473 & 203.17531 & 0.03 \\
\hline 19 & 9.00 & Pyrochlorophyll $b^{1}$ & $\mathrm{C}_{53} \mathrm{H}_{68} \mathrm{MgN}_{4} \mathrm{O}_{4}$ & 849.51640 & -0.03 & 849.51620 & & 0.21 \\
\hline 20 & 9.00 & Pheophytin $a$ derivate ${ }^{1}$ & $\mathrm{C}_{55} \mathrm{H}_{72} \mathrm{~N}_{4} \mathrm{O}_{5}$ & 869.55755 & 0.01 & 869.55795 & & -0.13 \\
\hline 21 & 9.10 & Chlorophyllide $b^{1}$ & $\mathrm{C}_{35} \mathrm{H}_{32} \mathrm{MgN}_{4} \mathrm{O}_{6}$ & 629.24050 & 0.01 & 629.22498 & & -0.76 \\
\hline 22 & 9.12 & Chlorophyll $b^{1}$ & $\mathrm{C}_{55} \mathrm{H}_{70} \mathrm{MgN}_{4} \mathrm{O}_{6}$ & 907.55824 & 0.01 & 907.55841 & & -0.19 \\
\hline 23 & 9.15 & Pyrochlorophyll $a^{1}$ & $\mathrm{C}_{53} \mathrm{H}_{70} \mathrm{MgN}_{4} \mathrm{O}_{3}$ & 835.53711 & 0.01 & 835.53746 & & -0.42 \\
\hline 24 & 9.18 & Pyrochlorophyllide $a^{1}$ & $\mathrm{C}_{33} \mathrm{H}_{32} \mathrm{MgN}_{4} \mathrm{O}_{3}$ & 557.23978 & -0.04 & 557.23992 & & -0.29 \\
\hline 25 & 9.26 & Pyrochlorophyllide $b$ & $\mathrm{C}_{33} \mathrm{H}_{30} \mathrm{MgN}_{4} \mathrm{O}_{4}$ & 571.21901 & 0.02 & 571.21902 & & 0.01 \\
\hline 26 & 9.28 & OH-Chlorophyll $a^{1}$ & $\mathrm{C}_{55} \mathrm{H}_{72} \mathrm{MgN}_{4} \mathrm{O}_{6}$ & 909.53746 & 0.05 & 909.53786 & $525.21366,553.20861$ & -0.95 \\
\hline 27 & 9.32 & Protochlorophyllide $a^{1}$ & $\mathrm{C}_{35} \mathrm{H}_{32} \mathrm{MgN}_{4} \mathrm{O}_{5}$ & 613.22959 & -0.01 & 613.22998 & & -0.64 \\
\hline 28 & 9.32 & 13-OH-Chlorophyllide $a^{1}$ & $\mathrm{C}_{35} \mathrm{H}_{34} \mathrm{MgN}_{4} \mathrm{O}_{6}$ & 631.24015 & 0.01 & 631.24054 & & -0.62 \\
\hline 29 & 9.32 & Divinyl Chlorophyll $a^{1}$ & $\mathrm{C}_{55} \mathrm{H}_{70} \mathrm{MgN}_{4} \mathrm{O}_{5}$ & 891.52691 & 0.04 & 891.52705 & $555.22506,614.23423$ & 0.21 \\
\hline 30 & 9.56 & Chlorophyll $a$ & $\mathrm{C}_{55} \mathrm{H}_{72} \mathrm{MgN}_{4} \mathrm{O}_{5}$ & 893.54262 & -0.03 & 893.54274 & $\begin{array}{c}555.22547,481.18779 \\
614.23848\end{array}$ & -0.17 \\
\hline 31 & 10.03 & Cryptoxanthin ${ }^{1}$ & $\mathrm{C}_{40} \mathrm{H}_{56} \mathrm{O}$ & 553.44040 & 0.01 & 553.44047 & $535.430052,461.37769$ & -0.15 \\
\hline
\end{tabular}


Table 1. Cont.

\begin{tabular}{|c|c|c|c|c|c|c|c|c|}
\hline Peak & rt & Compound & $\begin{array}{l}\text { Molecular } \\
\text { Formula }\end{array}$ & $\begin{array}{c}{[\mathrm{M}+\mathrm{H}]^{+}} \\
\text {DIMS-APCI }\end{array}$ & $\begin{array}{l}\text { Error ppm } \\
\text { DIMS-APCI }\end{array}$ & $\begin{array}{c}{[\mathrm{M}+\mathrm{H}]^{+}} \\
\text {LC-APCI-FT-ICR } \\
\text { MS }\end{array}$ & MS/MS & $\begin{array}{c}\text { Error ppm } \\
\text { LC-APCI-FT-ICR } \\
\text { MS }\end{array}$ \\
\hline 32 & 10.04 & Chlorophyll $a$ isomer & $\mathrm{C}_{55} \mathrm{H}_{72} \mathrm{MgN}_{4} \mathrm{O}_{5}$ & 893.54262 & -0.03 & 893.54274 & $\begin{array}{c}555.22547,481.18779 \\
614.23848\end{array}$ & -0.17 \\
\hline 33 & 10.10 & Chlorophyllide $a^{1}$ & $\mathrm{C}_{35} \mathrm{H}_{34} \mathrm{MgN}_{4} \mathrm{O}_{5}$ & 615.24526 & -0.04 & 615.2461 & & -0.34 \\
\hline 34 & 10.23 & Pheophytin $b^{1}$ & $\mathrm{C}_{55} \mathrm{H}_{72} \mathrm{~N}_{4} \mathrm{O}_{6}$ & 885.55233 & 0.14 & 885.53330 & & -0.09 \\
\hline 35 & 10.30 & 15-OH-Lactone-Chlorophyll $a^{1}$ & $\mathrm{C}_{55} \mathrm{H}_{73} \mathrm{MgN}_{4} \mathrm{O}_{7}$ & 925.53199 & 0.47 & 925.53324 & & 0.89 \\
\hline 36 & 10.47 & Pyropheophorbide $b^{1}$ & $\mathrm{C}_{33} \mathrm{H}_{32} \mathrm{~N}_{4} \mathrm{O}_{4}$ & 549.24967 & -0.08 & 549.24980 & & -0.31 \\
\hline 37 & 10.48 & 15-OH-Lactone-Pheophytin $a^{1}$ & $\mathrm{C}_{55} \mathrm{H}_{73} \mathrm{~N}_{4} \mathrm{O}_{7}$ & 903.56328 & -0.28 & 903.56341 & $\begin{array}{c}537.24965,547.23401 \\
607.25553\end{array}$ & -0.09 \\
\hline 38 & 10.79 & Chlorobactene $^{1}$ & $\mathrm{C}_{40} \mathrm{H}_{52}$ & 533.41416 & 0.03 & 533.41406 & & 0.21 \\
\hline 39 & 11.03 & Chlorophyll $a$ derivate I ${ }^{1}$ & $\mathrm{C}_{55} \mathrm{H}_{68} \mathrm{MgN}_{4} \mathrm{O}_{5}$ & 889.51122 & 0.08 & 889.51165 & & -0.41 \\
\hline 40 & 11.06 & Phytoene ${ }^{1}$ & $\mathrm{C}_{40} \mathrm{H}_{64}$ & 545.50810 & -0.03 & 545.50829 & & -0.39 \\
\hline 41 & 11.12 & 13-OH-Pheophorbide $a^{1}$ & $\mathrm{C}_{35} \mathrm{H}_{36} \mathrm{~N}_{4} \mathrm{O}_{6}$ & 609.27078 & -0.02 & 609.27091 & & -0.24 \\
\hline 42 & 11.12 & OH-Pheophytin $a$ & $\mathrm{C}_{55} \mathrm{H}_{73} \mathrm{~N}_{4} \mathrm{O}_{6}$ & 887.56810 & 0.01 & 887.56826 & $\begin{array}{c}531.23918,559.23402 \\
591.26022\end{array}$ & -0.17 \\
\hline 43 & 11.16 & $\beta$-carotene & $\mathrm{C}_{40} \mathrm{H}_{56}$ & 537.44547 & 0.01 & 537.44562 & $413.32058,445.38298$ & -0.27 \\
\hline 44 & 11.21 & Octadehydro- $\beta, \beta$-carotene ${ }^{1}$ & $\mathrm{C}_{40} \mathrm{H}_{48}$ & 529.38288 & 0.03 & 529.38303 & & -0.29 \\
\hline 45 & 11.41 & Pheophytin $a$ & $\mathrm{C}_{55} \mathrm{H}_{74} \mathrm{~N}_{4} \mathrm{O}_{5}$ & 871.57318 & 0.02 & 871.57254 & $\begin{array}{c}593.27615,533.25473 \\
519.23921\end{array}$ & 0.75 \\
\hline 46 & 11.68 & Pheophorbide $a^{1}$ & $\mathrm{C}_{35} \mathrm{H}_{36} \mathrm{~N}_{4} \mathrm{O}_{5}$ & 593.27583 & 0.02 & 593.27601 & & -0.27 \\
\hline 47 & 12.30 & Pyropheophorbide $a^{1}$ & $\mathrm{C}_{33} \mathrm{H}_{34} \mathrm{~N}_{4} \mathrm{O}_{3}$ & 535.27037 & 0.01 & 535.27058 & & 0.39 \\
\hline 48 & 12.30 & Pyropheophytin $a^{1}$ & $\mathrm{C}_{53} \mathrm{H}_{72} \mathrm{~N}_{4} \mathrm{O}_{3}$ & 813.56769 & 0.04 & 813.56787 & $\begin{array}{c}535.27058,507.27549, \\
461.23369\end{array}$ & -0.18 \\
\hline 49 & & $\delta$-tocopherol ${ }^{1}$ & $\mathrm{C}_{27} \mathrm{H}_{46} \mathrm{O}_{2}$ & 403.35706 & 0.01 & & & \\
\hline 50 & & $\gamma$-tocopherol ${ }^{1}$ & $\mathrm{C}_{28} \mathrm{H}_{48} \mathrm{O}_{2}$ & 417.37270 & 0.02 & & & \\
\hline 51 & & Phytofluene ${ }^{1}$ & $\mathrm{C}_{40} \mathrm{H}_{62}$ & 543.49242 & 0.01 & & & \\
\hline
\end{tabular}

${ }^{1}$ Detected for the first time in Spirulina (Arthrospira platensis); ${ }^{2}\left[\mathrm{M}+\mathrm{H}-\mathrm{H}_{2} \mathrm{O}\right]^{+} ;{ }^{3}\left[\mathrm{M}+\mathrm{H}-\mathrm{H}_{2} \mathrm{O}-\mathrm{H}_{2} \mathrm{O}\right]^{+}$. 

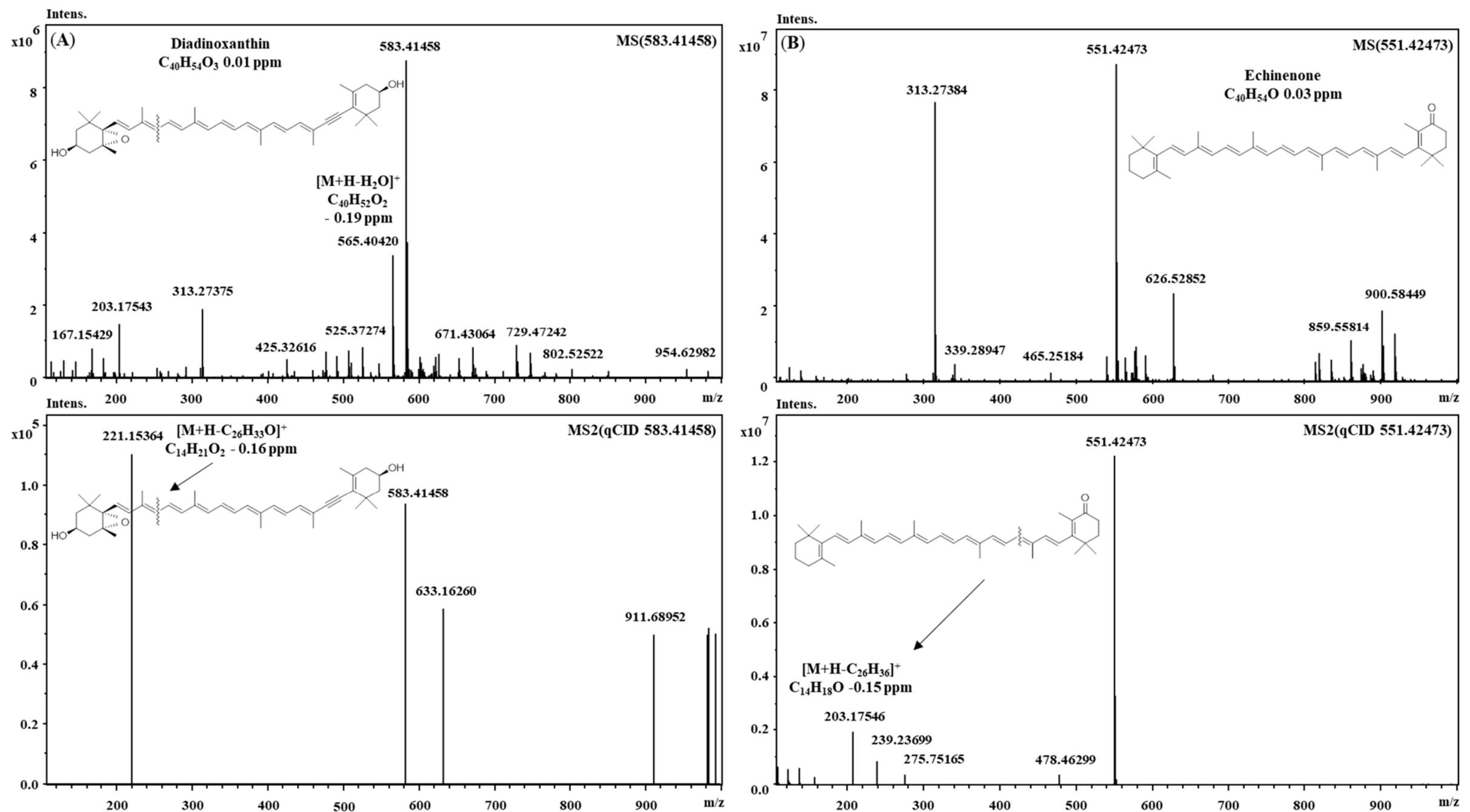

Figure 1. MS (top) and MS/MS (bottom) spectra showing structure elucidation and fragmentation pattern of peak 3 diadinoxanthin (A) and peak 18 echinenone (B). 


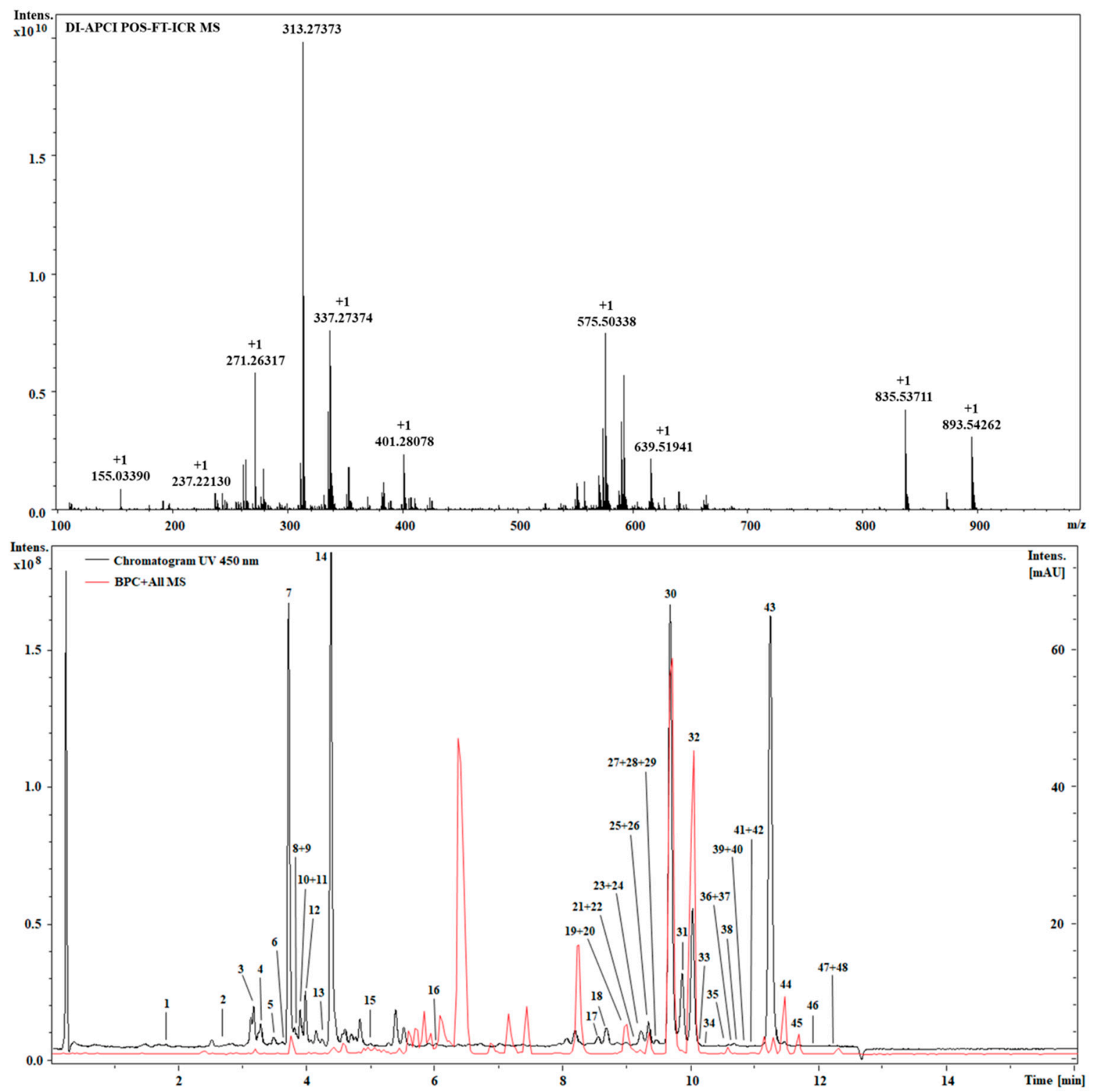

Figure 2. DIMS-APCI (top) and LC-APCI-FT-ICR MS (bottom) identification of Spirulina pigments.

\subsection{Quantitative Profile of Spirulina Pigments by UHPLC-PDA}

Separation of natural pigments is usually performed by C18 and C30 columns [21], the latter are usually best suited for the separation of geometric isomers. Numerous evidence indicates the benefits of using sub-3 and sub-2 micrometers particles, either fully (FPP) or superficially porous (SPP), in the analysis of natural compounds [22,23]. This has also been recently shown for carotenoids in UHPLC conditions [24], as well as SFC [25]. In this work, we employed and compared both $1.7 \mu \mathrm{m}$ FPP and SPP $\mathrm{C} 18$ and $2.6 \mu \mathrm{m}$ SPP C30 columns. As can be seen from Figure S1, separation on the three columns were similar, except that a better separation of alfa, trans and cis beta carotene was obtained on the C30. The employed column (namely Accucore ${ }^{\mathrm{TM}} \mathrm{C} 30$ ) is the only sub-3 micrometer $\mathrm{C} 30$ column on the market. The stationary phase is endcapped, which, in comparison to non-endcapped polymeric C 30 phases, provides no appreciable separation of isomers [21]. The employed gradients were optimized for instrument and column characteristics. The choice was made in order to obtain acceptable separations in less than $15 \mathrm{~min}$ analysis time; in this regard, it should be pointed out that the non-endcapped C30 columns employed in numerous papers are characterized by very long analysis times [26], which were unpractical for the scope of this study. Due to the high cost of standards, only major carotenoids were 
quantified, quantification was performed by PDA at the maximum of absorbance. The objective of this study was to highlight the profiles and differences among two commercial and one lab-made Spriulina-based products. Table 2 shows that the most abundant compounds were diatoxanthin $(363.96 \pm 1.03)$, zeaxanthin $(362.51 \pm 0.51)$ and beta carotene $(2388.83 \pm 14.94)$. Among the three formulations, both powders showed in total higher amounts of pigments with respect to tablets $(1637.86 \pm 8.41 \mu \mathrm{g} / \mathrm{g}$ and $2551.49 \pm 6.86 \mu \mathrm{g} / \mathrm{g}$, respectively vs. $1384.18 \pm 7.55 \mu \mathrm{g} / \mathrm{g})$. This aspect could be due to the different technological processes, during the production of final products. It is noteworthy that chlorophylls were highly abundant, but these were not quantified due to lack of standards. The employed method was able to resolve zeaxanthin from lutein, which are usually difficult to separate, and thus quantify, revealing that the latter was not present in the sample, as shown by the overlapped standards chromatogram in Figure S2. By taking advantage of the low dwell volume of the UHPLC system employed, the analysis time was kept under $15 \mathrm{~min}$ (10 $\mathrm{min}$ for the C18). Repeatability was established by triplicate injections of sample and solutions at low, medium, and high concentration levels of the calibration curve on the same day, and within two consecutive days; limits of detection (LODs) and quantification (LOQs) were calculated by the ratio between the standard deviation (SD) and analytical curve slope multiplied by 3 and 10, respectively. Results are reported in supplementary Tables S1 and S2. 
Table 2. Quantitative data, RSA $\%$ of single compounds and $\mathrm{IC}_{50}$ of different dietary supplements.

\begin{tabular}{|c|c|c|c|c|c|c|}
\hline & & $\begin{array}{l}\text { Dietary Supplement } \\
\text { Powder }\end{array}$ & Lab Made Powder & $\begin{array}{c}\text { Dietary Supplement } \\
\text { Tablet }\end{array}$ & \\
\hline \multicolumn{5}{|c|}{ Quantitative } & & \\
\hline Peak & Compounds & $\mu \mathrm{g} / \mathrm{g}$ & $\mu \mathrm{g} / \mathrm{g}$ & $\mu \mathrm{g} / \mathrm{g}$ & \multicolumn{2}{|c|}{ RSA \% } \\
\hline 1 & Diadinoxanthin & $28.01 \pm 0.11$ & $55.27 \pm 0.16$ & $30.79 \pm 0.05$ & \multicolumn{2}{|c|}{$15.07 \pm 0.17$} \\
\hline 2 & Alloxanthin/Canthaxanthin & $22.76 \pm 0.04$ & $26.38 \pm 0.17$ & $25.79 \pm 0.03$ & \multicolumn{2}{|c|}{$6.66 \pm 0.27$} \\
\hline 3 & Diatoxanthin & $100.11 \pm 0.22$ & $363.96 \pm 1.03$ & $78.33 \pm 0.29$ & \multicolumn{2}{|c|}{$14.45 \pm 0.23$} \\
\hline 4 & Antheraxanthin & $27.20 \pm 0.02$ & $31.60 \pm 0.15$ & $28.45 \pm 0.11$ & \multicolumn{2}{|c|}{$5.99 \pm 0.11$} \\
\hline 5 & Zeaxanthin & $113.76 \pm 0.15$ & $362.51 \pm 0.61$ & $91.95 \pm 0.32$ & \multicolumn{2}{|c|}{$10.02 \pm 0.05$} \\
\hline 6 & Echinenone & $24.95 \pm 0.16$ & $25.05 \pm 0.09$ & $32.57 \pm 0.15$ & \multicolumn{2}{|c|}{$4.54 \pm 0.15$} \\
\hline 7 & $\beta$-carotene & $1226.99 \pm 7.67$ & $1544.36 \pm 4.06$ & $988.47 \pm 6.10$ & \multicolumn{2}{|c|}{$16.23 \pm 0.30$} \\
\hline & & $\begin{array}{l}\text { Pietary Supplement } \\
\text { Powder (a) }\end{array}$ & $\begin{array}{l}\text { Lab Made Powder } \\
\text { (b) }\end{array}$ & $\begin{array}{c}\text { Dietary Supplement } \\
\text { Tablets }\end{array}$ & Ascorbic Acid & BHT \\
\hline $\mathrm{IC}_{50}(\mathrm{mg} / \mathrm{mL})$ & & $2.99 \pm 0.05$ & $1.21 \pm 0.02$ & $2.68 \pm 0.03$ & $0.03 \pm 0.002$ & $0.02 \pm 0.001$ \\
\hline
\end{tabular}




\subsection{Evaluation of Antioxidant Potential of Single Pigments by DPPH-UHPLC-PDA}

The DPPH free radical assay is well known as an easy and rapid way to determine antioxidant activity, and is widely used for natural and food samples. Regarding complex multianalyte samples, one of its drawbacks is its inability to provide information regarding the individual antioxidant potential of analytes. Contrariwise, if the assay is coupled with a separation technique, such as UHPLC, the method can be useful for the screening of individual antioxidants [27]. In this case, after the reaction with the radical, the peak areas (UV/Vis) of potential antioxidants would decrease [28]. In this study, a pre-column reaction with DPPH radical was performed prior UHPLC separation. Two crucial aspects are: the ratio between the concentration of DPPH and the extract, and the reaction time. If an excess of DPPH is employed, the differences in the antioxidant activity cannot be measured, since every peak just disappears into the UV/Vis trace; on the contrary, with an inadequate concentration of DPPH, no significant differences can be observed. After several tests, we found that the best conditions were obtained with $0.5-0.9 \mathrm{mM}$ of DPPH. The optimal reaction time was $30 \mathrm{~min}$, which was determined by injecting at different time intervals; after this point, no further changes in peak areas were observed, with the color of the solution being stably yellow. The UV/Vis chromatogram (450 nm) related to the separation of both untreated and DPPH-spiked Spirulina sample is shown in Figure 3. As can be appreciated, several peaks were significantly reduced, while others remained almost unchanged. In particular, among the pigments in Table 2 , as expected, $\beta$-carotene showed higher scavenging activity with respect to xanthophylls such as zeaxanthin and antheraxanthin, which is known to be related to the presence of hydroxyl substituents on the B-ring [29]. Interestingly, diadinoxanthin and diatoxanthin possessed a higher scavenging activity with respect to other xanthophylls. This difference is probably due to the triple bond, which is known to increase the oxidation potential, as previously reported [30,31]. These aspects have not been reported so far, and require further investigation with other antioxidant assays, such as ABTS. The comparison of the $\mathrm{IC}_{50}$ of the three dietary supplements revealed that the formulation with the lowest $\mathrm{IC}_{50}$ is the lab-made Spirulina powder $(1.21 \mathrm{mg} / \mathrm{mL})$, whereas the other dietary supplements possess similar values ( $2.99 \mathrm{mg} / \mathrm{mL}$ vs. $2.68 \mathrm{mg} / \mathrm{mL})$. This is clearly related to the highest amount of pigment being contained in the lab-made powder (b), whereas the high content of chlorophylls, which are known to be antioxidant compounds [32], in the powder (a) with respect to tablets results in a lower $\mathrm{IC}_{50}$. The DPPH-UHPLC method took only 40 min per sample comprising reaction. In comparison to online methods, which require an additional pumping system and a reactor coil, the employed setup is easier and can take full advantage of the higher efficiency and speed of UHPLC [27], not being affected by the extra-column contributions. 


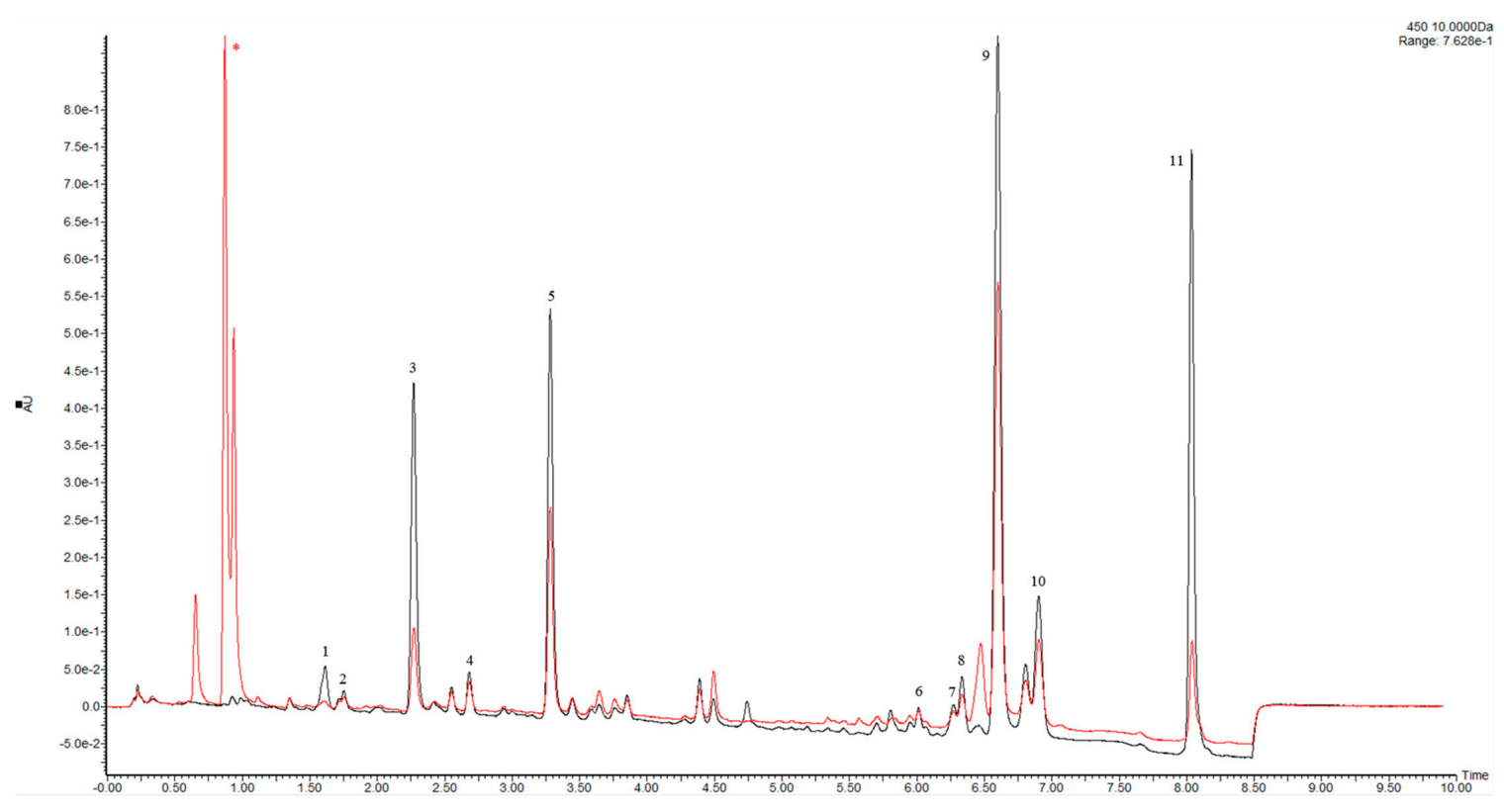

Figure 3. UV/Vis-UHPLC- $(450 \mathrm{~nm})$ chromatograms of Spirulina pigment extract before (black) and after (red) reaction with DPPH radical (marked with an asterisk). 


\section{Material and Methods}

\subsection{Chemicals}

Ultra-pure water $\left(\mathrm{H}_{2} \mathrm{O}\right)$ was obtained by a Direct-8 Milli-Q system (Millipore, Milan, Italy); LC-MS grade acetonitrile $(\mathrm{ACN})$, methanol $\left(\mathrm{CH}_{3} \mathrm{OH}\right)$, 2-propanol (IPA), water $\left(\mathrm{H}_{2} \mathrm{O}\right)$, ammonium acetate $\left(\mathrm{CH}_{3} \mathrm{COONH}_{4}\right)$, and standards of $\beta$-carotene, lutein, and zeaxanthin, were all purchased from Sigma-Aldrich (St. Louis, MO, USA). Spirulina powders and tablets were respectively purchased from FarmaLabor SRL (Canosa di Puglia, Barletta-Trani, Italy) and Dr. Giorgini (Bologna, Italy). Lab-made Spirulina powder was kindly donated by a local farmer.

\subsection{Sample Extraction}

Pigment extraction was carried out as follows. $350 \mathrm{mg}$ of Spirulina powder (tablets were prior pulverized in a mortar) were treated with $50 \mathrm{~mL}$ of ethanol fortified with $20 \mu \mathrm{g} / \mathrm{mL}$ of BHT. The sample was subjected to $15 \mathrm{~min}$ of ultrasound ( $550 \mathrm{~W}$ of power), then the suspension was stirred for $30 \mathrm{~min}$ at room temperature and then centrifuged $\left(10 \mathrm{~min} \times 6000 \mathrm{rpm}\right.$ at $\left.25^{\circ} \mathrm{C}\right)$. At the end, the supernatant was removed, and the pellet was retreated following the same protocol another four times. Finally, the supernatants were pooled and lyophilized. The same conditions were employed for each sample of Spirulina.

\subsection{Instrumentation}

High-resolution MS analyses were performed on a SolariX XR equipped with a 7T magnet (Bruker Daltonics, Bremen, Germany). An APCI source operating in positive ionization was used. For direct infusion mode, samples were injected with instrument syringe pump $(250 \mu \mathrm{L})$, while for LC-HRMS, an Ultimate 3000 UHPLC (Thermo Scientific, Bremen, Germany) system was employed. DPPH-UHPLC-PDA analyses were performed on an Acquity I class, equipped with a QDa mass detector (Waters, Milford, MA, USA) system.

\subsection{Columns}

A Waters ${ }^{\circledR}$ Acquity UPLC ${ }^{\circledR}$ BEH C18 $50 \mathrm{~mm} \times 2.1 \mathrm{~mm}, 1.7 \mu \mathrm{m}$ was employed for all analyses. A Thermo Accucore ${ }^{\mathrm{TM}} \mathrm{C} 30100 \mathrm{~mm} \times 2.1 \mathrm{~mm}, 2.6 \mu \mathrm{m}$ and a Phenomenex ${ }^{\circledR}$ (Castelmaggiore, Bologna, Italy) Kinetex ${ }^{\circledR}$ EVO C18 $100 \mathrm{~mm} \times 2.1 \mathrm{~mm}, 1.7 \mu \mathrm{m}$, were employed for purposes of comparison.

\subsection{DIMS and LC-HRMS Parameters}

The instrument was tuned with a standard solution of sodium trifluoracetate (NaTFA). Samples $\left(10 \mu \mathrm{g} / \mathrm{mL}\right.$ in $\left.\mathrm{CH}_{3} \mathrm{OH}\right)$ were infused at $50 \mu \mathrm{L} / \mathrm{min}$. Mass Spectra were recorded in broadband mode in the range 150-3000 m/z, with an ion accumulation of $20 \mathrm{~ms}$, with 200 scans using 8 million data points $(8 \mathrm{M})$. Nebulizing $\left(\mathrm{N}_{2}\right)$ and drying gases (air) were set at 1 and $4 \mathrm{~mL} / \mathrm{min}$, respectively, with a drying temperature of $200{ }^{\circ} \mathrm{C}$. MS/MS of the ion of interest was obtained by isolation in the quadrupole and ramping the collision energy manually. LC-HRMS analyses were carried out with the same parameters, with the exception of: 2 million data points were used (2M), ion accumulation was $80 \mathrm{~ms}$, nebulizing and drying gases were 2 and $8 \mathrm{~mL} / \mathrm{min}$, and drying temperature was $250{ }^{\circ} \mathrm{C}$. MS/MS was performed in data-dependent mode, and dynamic collision energy ramp was used. Compound: 2,2,4,4,6,6-Hexakis(2,2-difluoroethoxy)-1,3,5-triazatriphosphinine $(\mathrm{m} / \mathrm{z}$ 622.028960) (Apollo Scientific, Bredbury, UK) was employed as lock mass for LC-MS/MS. Mobile phases were: (A) $10 \mathrm{mM} \mathrm{CH}_{3} \mathrm{COONH}_{4}$ in $\mathrm{H}_{2} \mathrm{O} v / v$; (B) ACN/CH $3 \mathrm{OH} / \mathrm{IPA} 70 / 20 / 10$, flow rate was $0.4 \mathrm{~mL} / \mathrm{min}$, LC gradient was: $0 \mathrm{~min}, 40 \% \mathrm{~B}, 6.25 \mathrm{~min}, 85 \% \mathrm{~B}, 9.50 \mathrm{~min}, 92 \% \mathrm{~B}, 10 \mathrm{~min}, 98 \% \mathrm{~B}$ hold for $1 \mathrm{~min}$, column oven was set at $45^{\circ} \mathrm{C}, 2 \mu \mathrm{L}$ of sample was injected. The instrument was controlled by Bruker FTMS Control, MS spectra were elaborated with Compass Data Analysis version 4.2 (Bruker Daltonics, 
Bremen, Germany), identification of compounds based on accurate MS and MS/MS measurements was performed by Compound Crawler ver. 3.0 (Bruker).

\subsection{DPPH-UHPLC-PDA Parameters}

The determination of antioxidant activity was carried out as previously developed [27]. One hundred microliters of ethanolic extract of Spirulina $(2 \mathrm{mg} / \mathrm{mL})$ and $100 \mu \mathrm{L}$ of DPPH solution (ranging from 0.5 to $0.9 \mathrm{mM}$ ) in a 1:1 ratio were briefly mixed and allowed to react for $30 \mathrm{~min}$ in the dark at room temperature. $100 \mu \mathrm{L}$ of methanol was added to the Spirulina extract as control. After filtration with a $0.45-\mu \mathrm{m}$ filter, $2 \mu \mathrm{L}$ of sample solution were injected for UHPLC analysis with the following conditions: mobile phases were the same as in Section 3.5, while the gradient was tuned for the different LC instrument: $0.01 \mathrm{~min} 60 \% \mathrm{~B}, 0.75 \mathrm{~min} 75 \% \mathrm{~B}, 3.25 \mathrm{~min} 85 \% \mathrm{~B}, 5.00 \mathrm{~min} 95 \% \mathrm{~B}$, hold for $2 \mathrm{~min}, 7.01 \mathrm{~min}$ $100 \% \mathrm{~B}$, hold for $1 \mathrm{~min}$. Flow rate was $0.4 \mathrm{~mL} / \mathrm{min}$. Column oven temperature was set to $45^{\circ} \mathrm{C}$. PDA sampling rate was $20 \mathrm{~Hz}$, time constant $80 \mathrm{~ms}$, data acquisition was set in the range 190-800 nm, and chromatograms were monitored at $450 \mathrm{~nm}$. QDa mass analyzer was operated under Selected Ion Monitoring (SIM) in ESI positive ionization, by specifying the $m / z$ values of compounds detected with the HRMS approach. MassLynx 4.0 (Waters, Milford, MA, USA) was employed for data analysis.

The change in the pigments' peak areas of analytes $\left(P A_{\text {control }}\right)$ between control and DPPH-spiked $\left(P A_{\text {spiked }}\right)$ sample was used to evaluate the antioxidant power according to the following equation:

$$
\text { Radical scavenging }=\frac{P A_{\text {control }}-P A_{\text {spiked }}}{P A_{\text {control }}} \times 100
$$

where $\left(P A_{\text {control }}\right)$ refers to the Spirulina extract diluted with methanol, whereas $\left(P A_{\text {spiked }}\right)$ refers to the DPPH solution mixed with the Spirulina extract. The percentage of DPPH scavenging versus the concentration of samples was plotted. Whereas, by monitoring the DPPH peak at $517 \mathrm{~nm}$, the concentration of ethanolic extract necessary to decrease the DPPH concentration by $50 \%$ was obtained by interpolation from a linear regression analysis and denoted as the $\mathrm{IC}_{50}$ value $(\mu \mathrm{g} / \mathrm{mL})$. All determinations were performed in triplicate.

\subsection{Qualitative and Quantitative Analysis}

Since standards were not available for all compounds, zeaxanthin, lutein and $\beta$-carotene were selected as external standards for the quantification. Stock solutions $(1 \mathrm{mg} / \mathrm{mL})$ were prepared in methanol/MTBE (70:30) and the calibration curves were obtained in a concentration range, respectively, of $0.25-25 \mu \mathrm{g} / \mathrm{mL}\left(R^{2}=0.999\right), 1-100 \mu \mathrm{g} / \mathrm{mL}\left(R^{2}=0.996\right)$, and $1-100 \mu \mathrm{g} / \mathrm{mL}\left(R^{2}=0.996\right)$, with seven concentration levels, and triplicate injections of each level were run. Peak areas were plotted against corresponding concentrations. The amount of the compounds in the sample was expressed as micrograms per gram. Xanthophylls were quantified as zeaxanthin equivalents.

\section{Conclusions}

The developed analytical strategy, consisting of FT-ICR and UHPLC-PDA, provided a detailed definition of the Spirulina pigment fraction. DIMS-FT-ICR, thanks to its ultra-high resolution and mass accuracy, is a promising tool for in-depth profiling of microalgae pigments. The DPPH-UHPLC-PDA method revealed that two xanthophylls, namely diadinoxanthin and diatoxanthin, possess relevant radical scavenging activity. This study further confirms the content of high-value biocompounds in Spirulina, and its importance for the nutraceutical and pharmaceutical field.

Supplementary Materials: The Supplementary Materials are available at http:/ /www.mdpi.com/1420-3049/23/ 5/1152/s1.

Author Contributions: Conceptualization, E.So.; Data curation, G.P.; Funding acquisition, P.C.; Investigation, G.M.C. and E.Sa.; Methodology, F.S.; Project administration, R.P.A.; Software, A.B.; Supervision, C.O. and F.D.P.; Writing—original draft, E.So. 
Acknowledgments: The authors would like to thank Matthias Witt from Bruker Daltonics for his support.

Conflicts of Interest: The authors declare no conflict of interest.

\section{References}

1. Siró, I.; Kápolna, E.; Kápolna, B.; Lugasi, A. Functional food. Product development, marketing and consumer acceptance-A review. Appetite 2008, 51, 456-467. [CrossRef] [PubMed]

2. Singh, S.; Kate, B.N.; Banerjee, U.C. Bioactive Compounds from Cyanobacteria and Microalgae: An Overview. Crit. Rev. Biotechnol. 2005, 25, 73-95. [CrossRef] [PubMed]

3. De Jesus Raposo, M.F.; de Morais, R.M.; de Morais, A.M. Health applications of bioactive compounds from marine microalgae. Life Sci. 2013, 93, 479-486. [CrossRef] [PubMed]

4. Khan, M.I.; Shin, J.H.; Kim, J.D. The promising future of microalgae: Current status, challenges, and optimization of a sustainable and renewable industry for biofuels, feed, and other products. Microb. Cell Fact. 2018, 17, 36. [CrossRef] [PubMed]

5. Khan, Z.; Bhadouria, P.; Bisen, P.S. Nutritional and Therapeutic Potential of Spirulina. Curr. Pharm. Biotechnol. 2005, 6, 373-379. [CrossRef] [PubMed]

6. Dillon, J.C.; Phuc, A.P.; Dubacq, J.P. Nutritional value of alga Spirulina. World Rev. Nutr. Diet. 1995, 77, 32-46. [CrossRef] [PubMed]

7. Rao, A.V.; Rao, L.G. Carotenoids and human health. Pharmacol. Res. 2007, 55, 207-216. [CrossRef] [PubMed]

8. Gong, M.; Bassi, A. Carotenoids from microalgae: A review of recent developments. Biotechnol. Adv. 2016, 34, 1396-1412. [CrossRef] [PubMed]

9. Guedes, A.C.; Amaro, H.M.; Malcata, F.X. Microalgae as Sources of Carotenoids. Mar. Drugs 2011, 9, 625-644. [CrossRef] [PubMed]

10. Mendiola, J.A.; Marín, F.R.; Hernández, S.F.; Arredondo, B.O.; Señoráns, F.J.; Ibañez, E.; Reglero, G. Characterization via liquid chromatography coupled to diode array detector and tandem mass spectrometry of supercritical fluid antioxidant extracts of Spirulina platensis microalga. J. Sep. Sci. 2005, 28, 1031-1038. [CrossRef] [PubMed]

11. Hynstova, V.; Sterbova, D.; Klejdus, B.; Hedbavny, J.; Huska, D.; Adam, V. Separation, identification and quantification of carotenoids and chlorophylls in dietary supplements containing Chlorella vulgaris and Spirulina platensis using High Performance Thin Layer Chromatography. J. Pharm. Biomed. Anal. 2018, 148, 108-118. [CrossRef] [PubMed]

12. Mendiola, J.A.; Jaime, L.; Santoyo, S.; Reglero, G.; Cifuentes, A.; Ibañez, E.b.; Señoráns, F.J. Screening of functional compounds in supercritical fluid extracts from Spirulina platensis. Food Chem. 2007, 102, 1357-1367. [CrossRef]

13. Rao, A.R.; Baskaran, V.; Sarada, R.; Ravishankar, G.A. In vivo bioavailability and antioxidant activity of carotenoids from microalgal biomass-A repeated dose study. Food Res. Int. 2013, 54, 711-717. [CrossRef]

14. La Barbera, G.; Capriotti, A.L.; Cavaliere, C.; Montone, C.M.; Piovesana, S.; Samperi, R.; Chiozzi, R.Z.; Laganà, A. Liquid chromatography-high resolution mass spectrometry for the analysis of phytochemicals in vegetal-derived food and beverages. Food Res. Int. 2017, 100, 28-52. [CrossRef] [PubMed]

15. Forcisi, S.; Moritz, F.; Kanawati, B.; Tziotis, D.; Lehmann, R.; Schmitt-Kopplin, P. Liquid chromatography-mass spectrometry in metabolomics research: Mass analyzers in ultra high pressure liquid chromatography coupling. J. Chromatogr. A 2013, 1292, 51-65. [CrossRef] [PubMed]

16. Brown, S.C.; Kruppa, G.; Dasseux, J.L. Metabolomics applications of FT-ICR mass spectrometry. Mass Spectrom. Rev. 2005, 24, 223-231. [CrossRef] [PubMed]

17. Fu, W.; Magnúsdóttir, M.; Brynjólfson, S.; Palsson, B.Ø.; Paglia, G. UPLC-UV-MSE analysis for quantification and identification of major carotenoid and chlorophyll species in algae. Anal. Bioanal. Chem. 2012, 404, 3145-3154. [CrossRef] [PubMed]

18. Van Breemen, R.B.; Dong, L.; Pajkovic, N.D. Atmospheric Pressure Chemical Ionization Tandem Mass Spectrometry of Carotenoids. Int. J. Mass Spectrom. 2012, 312, 163-172. [CrossRef] [PubMed]

19. Juin, C.; Bonnet, A.; Nicolau, E.; Bérard, J.B.; Devillers, R.; Thiéry, V.; Cadoret, J.P.; Picot, L. UPLC-MSE Profiling of Phytoplankton Metabolites: Application to the Identification of Pigments and Structural Analysis of Metabolites in Porphyridium purpureum. Mar. Drugs 2015, 13, 2541-2558. [CrossRef] [PubMed] 
20. Sommella, E.; Pagano, F.; Salviati, E.; Chieppa, M.; Bertamino, A.; Manfra, M.; Sala, M.; Novellino, E.; Campiglia, P. Chemical profiling of bioactive constituents in hop cones and pellets extracts by online comprehensive two-dimensional liquid chromatography with tandem mass spectrometry and direct infusion Fourier transform ion cyclotron resonance mass spectrometry. J. Sep. Sci. 2018, 41, 1548-1557. [CrossRef] [PubMed]

21. Rivera, S.M.; Canela-Garayoa, R. Analytical tools for the analysis of carotenoids in diverse materials. J. Chromatogr. A 2012, 1224, 1-10. [CrossRef] [PubMed]

22. Sommella, E.; Pepe, G.; Pagano, F.; Ostacolo, C.; Tenore, G.C.; Russo, M.T.; Novellino, E.; Manfra, M.; Campiglia, P. Detailed polyphenolic profiling of Annurca apple (M. pumila Miller cv Annurca) by a combination of RP-UHPLC and HILIC, both hyphenated to IT-TOF mass spectrometry. Food Res. Int. 2015, 76, 466-477. [CrossRef] [PubMed]

23. Capriotti, A.L.; Cavaliere, C.; La Barbera, G.; Montone, C.M.; Piovesana, S.; Zenezini Chiozzi, R.; Laganà, A. Chromatographic column evaluation for the untargeted profiling of glucosinolates in cauliflower by means of ultra-high performance liquid chromatography coupled to high resolution mass spectrometry. Talanta 2018, 179, 792-802. [CrossRef] [PubMed]

24. Bijttebier, S.; Els D’Hondt, E.; Noten, B.; Hermans, N.; Apers, S.; Voorspoels, S. Ultra high performance liquid chromatography versus high performance liquid chromatography: Stationary phase selectivity for generic carotenoid screening. J. Chromatogr. A 2014, 1332, 46-56. [CrossRef] [PubMed]

25. Giuffrida, D.; Zoccali, M.; Giofrè, S.V.; Dugo, P.; Mondello, L. Apocarotenoids determination in Capsicum chinense Jacq. cv. Habanero, by supercritical fluid chromatography-triple-quadrupole/mass spectrometry. Food Chem. 2017, 231, 316-323. [CrossRef] [PubMed]

26. Giuffrida, D.; Pintea, A.; Dugo, P.; Torre, G.; Raluca, M.P.; Mondello, L. Determination of Carotenoids and their Esters in Fruits of Sea Buckthorn (Hippophae rhamnoides L.) by HPLC-DAD-APCI-MS. Phytochem. Anal. 2012, 23, 267-273. [CrossRef] [PubMed]

27. Sommella, E.; Pepe, G.; Pagano, F.; Conte, G.; Carimi, F.; Tenore, G.C.; Novellino, E.; Manfra, M.; Russo, M.; Campiglia, P. Rapid Screening of Antioxidant Anthocyanins in Autochthonous Nero d'Avola Grape Clones by Pre-column DPPH Reaction Coupled to UHPLC-UV/Vis-IT-TOF: A Strategy to Combine Chemical data and Genetic Diversity. Food Anal. Methods 2016, 10, 2780-2790. [CrossRef]

28. Sommella, E.; Pagano, F.; Pepe, G.; Ostacolo, C.; Manfra, M.; Chieppa, M.; Di Sanzo, R.; Carabetta, S.; Campiglia, P.; Russo, M. Flavonoid Composition of Tarocco (Citrus sinensis L. Osbeck) Clone "Lempso" and Fast Antioxidant Activity Screening by DPPH-UHPLC-PDA-IT-TOF. Phytochem. Anal. 2017, 28, 521-528. [CrossRef] [PubMed]

29. Jiménez-Escrig, A.; Jiménez-Jiménez, I.; Sánchez-Moreno, C.; Saura-Calixto, F. Evaluation of free radical scavenging of dietary carotenoids by the stable radical 2,2-diphenyl-1-picrylhydrazyl. J. Sci. Food Agric. 2000, 80, 1686-1690. [CrossRef]

30. Frank, H.A.; Young, J.; Britton, G.; Cogdell, R.J. The Photochemistry of Carotenoids; Springer: Dordrecht, The Netherlands, 1999; pp. 203-222.

31. Ngo, T.C.; Dao, D.Q.; Nguyen, M.T.; Nam, P.C. A DFT analysis on the radical scavenging activity of oxygenated terpenoids present in the extract of the buds of Cleistocalyx operculatus. RSC Adv. 2017, 7, 39686-39698. [CrossRef]

32. Lanfer-Marquez, U.M.; Barros, R.M.C.; Sinnecker, P. Antioxidant activity of chlorophylls and their derivatives. Food Res. Int. 2005, 38, 885-891. [CrossRef]

Sample Availability: Samples of the compounds are available from the authors. 